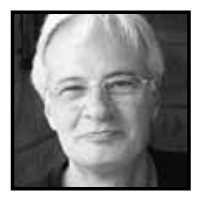

\title{
Volunteerism as an Agent of Transformation
}

\author{
Irving Lee Rother, Sir Wilfrid Laurier School Board
}

\begin{abstract}
I once believed that everything I knew about learning and teaching was the result of being a student and a teacher in schools and universities. But that was learning and teaching for a specific purpose and audience, structured for the here and now, in formal, familiar, comfortable settings with people who shared common experiences and interests. Since 2003 I have been volunteering and working with youth and educators in developing and post-conflict countries including Palestine, Nigeria, and Kenya. However, it is only within the last few years that I have come to realize that my volunteerism has provided me with informal learning opportunities that have led me to better understand who I am as a person, educator, and learner.
\end{abstract}

\section{Introduction}

"The central problem of an education based on experience is to select the kind of present experiences that live fruitfully and creatively in subsequent experience." (Dewey, 1938, pp. 27-28)

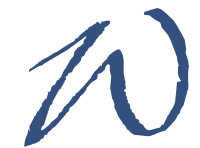

e tend to think of volunteering as a noble act that involves giving one's time and abilities for the betterment of those less fortunate. It is not intended to be about one's self. Still, after a decade of volunteering with youth media non-government organizations (NGOs) in Palestine, Nigeria, and South Africa as well as teacher training in Kenya, I now recognize the intense, informal learning that comes from volunteering. Most of all I have come to understand that my volunteerism is in essence about transformational moments in my life. 
To illustrate the impact volunteerism had on me as an educator and as a person, I have chosen the following accounts of "my adventures" taken from my journals in the Middle East and Africa between 2003 and 2010.

Each of these accounts demonstrates that teacher volunteerism offers countless opportunities for informal learning. In essence what follows are excerpts of professional development that can only be provided outside of formal educational settings. Each account is an excellent example of Freire's (1970) insistence that an educational activity is in the lived experience of participants.

\section{The Dialogue}

Some may think that to affirm dialogue-the encounter of women and men in the world in order to transform the world-is naively and subjectively idealistic. There is nothing, however, more real or concrete than people in the world and with the world, than humans with other humans. (Freire, 1970, p. 129)

Paulo Freire's (1970) work as it applies to informal learning has particular significance for the purpose of this paper. My first "adventure" illustrates Freire's notion that the conversation of the informal educator is dialogical in nature, is a two-way conversation in which both parties are on the same level of respect, and is an attempt to seek understanding.

From August to September 2003, I was a curriculum framework and learning outcome consultant at the Ministry of Education in Amman, Jordan. During my tenure in Jordan I was invited by a Palestinian friend to meet with a group of fifteen teens and young adults who all belonged to a youth group of which my friend was the director. The aim of the group was to create a dialogue with its Israeli counterparts.

Some of the youth had completed their secondary schooling a few months before; others were university students, and still others were unemployed. What they all had in common, aside from being Palestinian, was that they were all male and were children, teens or born during the first Intifada and witnesses or participants in the second uprising. Many were members of Arafat's Fatah Movement. Some had participated in violent confrontations with the Israeli military. Almost all of them had stories about relatives and/or friends who had been or were imprisoned. All of them were disenfranchised, angry, and understandably depressed. In fact, the situation at the time of my visit was extremely tense. The morning I left Jordan for Ramallah the 
United Nations building in Iraq had been bombed. As well, there had been a suicide bombing in Israel and a retaliatory assassination of a Hamas leader. As a response to the violence, Israeli tanks had moved into Ramallah earlier in the day and then stationed themselves on the outskirts not long after I arrived.

I must admit that upon hearing of the confrontations, I questioned whether I should continue with my plans to go to Ramallah that morning. Before I could change my mind, I quickly hopped onto the bus to the border checkpoint. As it turned out, my decision to attend the meeting was in itself what I believe my first ever transformation from a teacher and consultant to someone who wanted to learn about the lives of young people in a place and time that was outside of my comfort zone (i.e., in the safety of a classroom). Indeed, I believe that my decision to attend the meeting and what followed was a crucial point in sparking many questions about who I was as a teacher, a learner, and a person.

The meeting took place after the sun went down. Whether this was intended as a security measure or just practical I did not know. Still, as I sat in the room surrounded by the youth, the darkness of the night seemed to me as if I was involved in some sort of clandestine operation and only added to my apprehension as well as to the tense mood that resulted from the violent incidents that day. The description here is important since it was my first experience in such an unstable setting and, as such, contributed to my transformation.

Indeed, it was easily apparent that the youth at the meeting were on edge. The dialogue between the youth and I started slowly with the expected polite introductions, followed by an overview of the "situation" in the region, and how it had affected them personally. In fact, for the first half hour the youth seemed unexpectedly subdued. I started to worry that the meeting was beginning to resemble the first day of one of my university classes back home where the students refrain from being animated as they cautiously check me out. However, the atmosphere in the room changed when I asked: "So, what do you think about how the conflict is reported in the Western media?" Suddenly, several hands went up all at once. Others spoke openly, not patient enough to wait for someone to call upon them to speak. Not unexpectedly, their response was:

The media lie. It's always from the Israeli point of view; they make us all look like terrorists. The news media don't make a distinction between "terrorists" and Palestinians. When an Israeli is killed it's a tragedy. But when a Palestinian is killed it's retribution. 
In other words, they saw the Western news media as supportive of the United States' pro-Israel lobby. I was not surprised by their response, but I was surprised by the passion in their eyes and the heated discussion that stemmed from my question. But what I found most interesting was not so much how they spoke but rather that the discussion was not directed at me but at each other; after all as a "visiting scholar," I was supposed to be the focus of attention. My understanding of the Arabic language is limited to functional literacy, so I relied on one of the group organizers to translate bits and pieces of the discussions that were happening all around me. In any event, I was content at this point to be the observer. I began to get the impression that the Western media's construct of the "Palestinian situation" was a topic they had either not spoken of at length before or at the very least had not discussed in an open forum.

I was so caught up in my observations of the youth that I was taken off guard when they asked me what Canadians thought of Palestinians. I explained that I could not speak for all Canadians, only for myself. Still, I admitted that the images in television news media indeed presented a negative image of male, rock-throwing Palestinian youth. I also pointed out that such images of teenagers throwing rocks at armed Israeli soldiers seemed to me like a David versus Goliath confrontation. I explained that I was not angry at the teens themselves but rather with those Palestinian adults who encouraged them. As the dialogue continued, I realized that they were not so much looking to get me to side with the Palestinian cause, but rather were anxious to dispel stereotypes I may have acquired through the Western media about the conflict and about the image of Palestinians in particular.

In retrospect, I am not sure what I really expected to gain from meeting with the youth, but the opportunity served to prepare me for more such experiences. What I am sure of is that the experience of meeting the Palestinian youth had a transformational effect on me. Mezirow's theory of "transformative learning" (1990) suggests that reflection is often generated when encountering a "disorienting dilemma," which is an apt description of my encounter with the Palestinian youth. Indeed, immediately following the experience I felt a sense of disorientation, which while uncomfortable even today, has made me more inclined to reflect on my experiential learning, an activity I am confident I would not have previously realized. From a professional perspective, the experience led me to revisit my role as an educator, in particular the need to situate my teaching in a real-world, authentic context that problematizes the status quo. 


\section{Samuel and Me}

To paraphrase Freire (1970), the sum of our experience determines the people we become. He contended that it is not enough for people to come together in dialogue in order to gain knowledge of their social reality. They must act together in order to critically reflect upon their reality and transform it through further action and critical reflection. His idea of praxis suggests that there is a dialectical interplay between the way in which history and culture help shape people.

I first met Samuel Mbogo in July 2009 at the Utimishi Boys Secondary School in Gigil, Kenya, a small town about two hours from Nairobi. I was in Gigil as one of eight Canadians and two Americans, all members of a nonprofit volunteer organization called Education Beyond Borders (EBB). Our reason for being there was to provide professional development sessions to more than sixty Kenyan educators. Samuel was one of several Kenyan teachers chosen as facilitators whose role was to develop professional development workshops, along with EBB members, for Kenyan educators who were set to arrive in the coming week.

For the next week Samuel and I worked together planning the presentations. It was during this time that our friendship grew. We talked about a variety of topics related to our teaching as well as more personal things like family. It's a cliché but we immediately felt as if we had known each other for a long time.

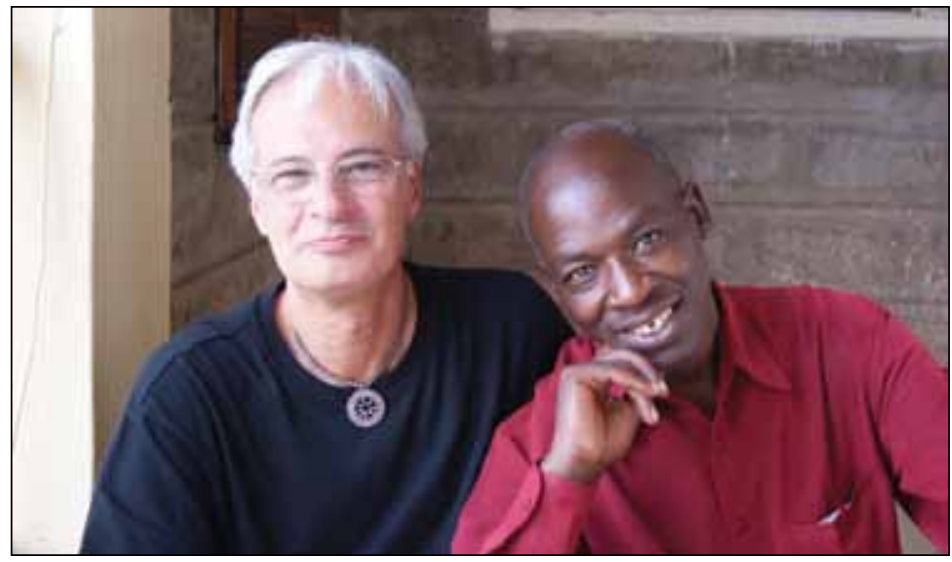

Fig. 1: The author and Samuel

A true relationship is built on a mutual understanding of each other's beliefs, values, hopes, and fears. These formed the basis for our dialogue concerning the state of education in our respective countries and in many ways our shared philosophy of education, which Samuel described in the following way: 
Education is life itself. It adds value to life. When one is well educated he has the ability to change the world around him for the better. On a practical sense, education enables job opportunities and improves ability to reason. (Samuel Mbogo, personal communication, July 2009)

We both grumbled about the large numbers of students in our classroom, though thirty-six in my classroom does not compare to the hundred in Samuel's class. Educators in Quebec fear what many see as increases in students' disrespect for teachers and major discipline problems such as bullying. While issues of discipline exist in Samuel's school, considering the large class numbers, there are fewer instances of serious behavior problems. The more resources I have for my students, the more I want. Samuel is content just having basics such as pencils and books for each student. I lament over the lack of parent involvement and support. While parent participation in Samuel's school is very limited, most parents wish for the opportunity to be more involved. However, in many instances providing for fundamental daily wants is in itself a struggle. Parents of my students often complain about the lack of homework or that their child has too much homework. Most parents of children in Samuel's school do not have the literacy levels that enable them to assist with homework. It is difficult to motivate my students. Some of Samuel's primary and secondary students walk several kilometers to school each day. Moreover, the vast majority desperately wants to be in school, even if they must wear a school uniform, often paid for by parents without complaint, though poverty is their lifestyle. While the wearing of uniforms is always a topic of heated discussion in the schools in which I have taught, in my thirty-five years not one student has had to wear a uniform.

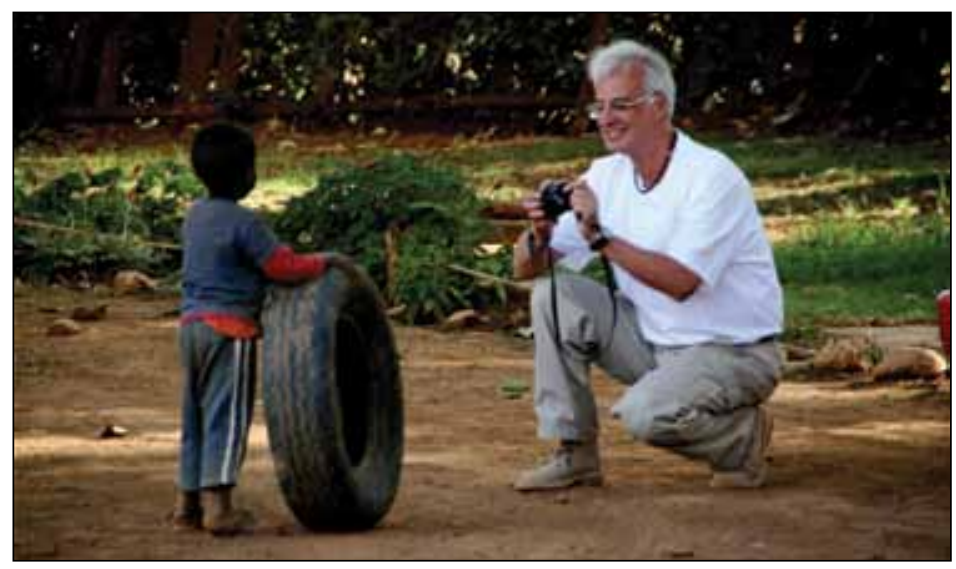

Fig. 2: Michael, a boy I befriended at the Nanyuki Orphanage in Kenya 


\section{The Ceremony}

Often accounts of friendship between a volunteer and an individual in the host country follow a typical narrative plot line, i.e., a beginning, middle, and end. As will become apparent in the following excerpt of Samuel and I, the story continues.

Samuel and I have kept in constant communication through email. In one of our earlier correspondences, we reminisced about our time together. Samuel's email suggested that we be "spiritually joined as brothers through a ritual of unification" (Samuel Mbogo, personal communication, July 2009). That is, I would be welcomed into Samuel's tribe, the Kikuyu. The ceremony was set for August 2010 when I returned to Kenya.

At 9:00 a.m. on the day of the ceremony (August 12, 2010) I was driven to Samuel's home, located high in the mountain village of Eburru. The hour drive seemed much longer since the road was really a series of trenches. We were met at the entrance road to Samuel's house by the beautiful and melodic sound of women singing and clapping. They led us to our seats in front of Samuel's home. As is the tradition, the men sit and talk while the women cook.

After this, we ate and listened to the senior elder speak of Eburru's history. Speaking through an interpreter, he recounted the colonial days when the "white" British controlled the Kikuyu land and people. Following his presentation I was led into Samuel's home where three of the elders "interviewed" me to ensure that I was worthy of being accepted as a village member and Kikuyu tribesman.

Following the interview I was led down a hill to a place under the trees for a ritual ceremony in which meat was shared among us. I was then led back up the hill back to Samuel's home. Over the next few hours we ate, sang, prayed, and danced. The final activity involved the placing of a thin ring of goatskin around my neck and a small piece served as a ring on my index finger. Prayers were said and I later learned that the ceremony represented my rebirth. I was given the name Chege Mwangi. The ceremony concluded with more singing and dancing. As a result of the honor bestowed on me by the villagers of Eburru I have come to understand that, regardless of culture and distance or our personal stories, we are interconnected. I also gained an appreciation for the different ways we each learn how our lives are shaped.

Dialogue, defined by Freire (1970), is encounter mediated by the world, in order to name the world. The bond I had with Samuel transformed me into an authentic global citizen. Professionally, I am aware that as a member of a global learning 
community I must ensure that both my students and my colleagues take on the assignment of challenging hegemonic assumptions, in particular those related to destiny, power, and diversity.

\section{Nigeria, the Cost of Transformation}

For apart from inquiry, apart from the praxis, individuals cannot be truly human. Knowledge emerges only through invention and re-invention, through the restless, impatient, continuing, hopeful inquiry human beings pursue in the world, with the world, and with each other. (Freire, 1970, p. 72)

In March 2006 I was invited by two nonprofit Nigerian NGOs (Youth for Technology and Teen World) to work on media literacy projects with children and teens in several urban and rural schools in Nigeria. Of all the locations I have visited overseas, Nigeria has had the most lasting impact. My experience in the most populated and poverty-stricken country in Africa made me reflect on what we in the West recognize as a school and teaching. I do not believe that my colleagues back home would recognize the environments I worked in as a school. To understand schooling in Nigeria, it is important to have a sense of the larger setting in which the schools are situated.

Nigeria is the most populated country in Africa. It is also one of the poorest. Most people live on less than $\$ 2$ a day. I visited at least half a dozen schools, some in large cities such as Lagos and others in small villages like Owerri. Driving from one location to another, sometimes on the same day, took literally hours through streets that were either paved and potholed or hardened red mud. Vehicles of all sorts, from large trucks to whole families seated on one scooter, clogged the streets. Observance of traffic regulations are for the most part ignored.

On one eight-hour drive to a school, traffic was not the only stumbling block as we were stopped numerous times by several policemen in black uniforms, each carrying a large baton and an AK-47 weapon. While I had similar experiences in Palestine, the image of the policeman and the crude roadblocks, which was really nothing more than scrap metal and wood arranged like a small maze, made for a more ominous experience. Being in a hurry to get to the next school before dark, which we did not accomplish, my traveling companions decided that they would not stop at each roadblock but rather merely slow down, wave their identity cards at the policemen and step on the accelerator. Of course I had no such card. At each roadblock policemen yelled at us to stop, often raising their batons and sometimes their guns. Sitting in the back seat I could not help but feel frightened. But somehow we made it to the next school without any real incident. 
Each of the schools I was taken to was really not much more than large rough stone blocks covered by tin roofs. Literally hundreds of children sat huddled three to a desk, made in most cases from scrap wooden boards. Few of the children had paper or pencils. For the most part the only light came from the glassless openings in the wall, which served as "windows." Dust poured in through the windows.

Instruction was nothing more that "chalk and talk," repetition, and rote learning, what Freire (1970) called "banking education," in which the teacher is the depositor and the students are the depositories.

The schools I visited in Nigeria were similar to many of the schools I have seen in other parts of Africa but none seemed to impress upon me a more perfect example of what Freire (1970) wrote about in his seminal book, Pedagogy of the Oppressed, concerning the state of a society in which one class of people remains embedded in poverty while another class of people benefit from the efforts of the lower class.

Informal discussions with Nigerian teachers and other educators demonstrated their dedication and their belief in the value of youth and education. But I could not help think that they also expressed feelings of being overwhelmed. Perhaps I am being too harsh but I cannot help but think of Nigerian schools as places of struggle.

Although I was only in Nigeria for a month, it seemed much longer. By the end of my stay in Nigeria, I found myself both emotionally and physically exhausted and felt a sense of relief when I boarded the plane home. In fact, during my first week home I declined to describe or speak of my experiences in Nigeria, even to family.

I learned a lot about myself in Nigeria. I learned that I was naive. I was naive in that I felt my previous experiences in Palestine and other parts of the Middle East had prepared me for what I would encounter in Nigeria. I had yet to learn that I was not as experienced as I assumed. Nigeria taught me that not only was I naive, but also that if I continue to work in places of extreme poverty and despair, I will have to find ways of controlling the emotional impact these places have on me.

In my teaching I constantly focus on my students' outcomes while ignoring my own personal accountability. I learned in Nigeria that my personal and professional transformation comes at a cost: if I continue to volunteer in settings dominated by inequality and despair, I will have to dig deep to summon the resiliency to adapt. 
Nigeria made me aware of the fact that my volunteerism can be both exciting and exhausting.

\section{Volunteerism and Pedagogy of Teacher Education}

I am convinced that my non-formal volunteer learning experiences described in this essay, and many more like them, either triggered or at the very least reinforced my belief in a pedagogy of teacher education which has as its primary tenet the notion that without experience, real learning or understanding of issues, ideas, concepts, or situations cannot occur. Kolb's experiential learning model (1984) provides a framework from which to contemplate volunteerism as an agent of transformation.

First, as a result of each volunteer experience, I as a learner was involved in a "concrete" exploration of issues related to gender, multiculturalism, literacy, vocational training, special needs, technological innovation, and delivery of instruction. I have long believed that my students and their peers have little exposure and therefore lack knowledge regarding not only global issues but also regarding these very issues on a local level. Volunteering in developing and post-conflict countries awakened me to the existence of these issues and the crucial need to involve my students in the study of these topics in the context of a safe learning environment.

Second, through the act of reflection, of which this essay is but one exercise, I have the opportunity to publicly share and analyze the experiences which leads me to not only process and conceptualize each experience but more importantly to: 1) question what I expected with what actually happened; 2) consider what was the most difficult and easiest part of the experiences; 3 ) speculate as to what were the most important aspects; 4) compare and contrast one experience with another. Finally, how through reflection and retrospection can I set aside past experiences so that with each new project I can begin again? These are all questions I constantly ask my students as they participate in their own experiences in school, the workplace, with their teachers, peers, and family.

Third, through conceptualizing the experiences I am better prepared to ask, "What did I learn about myself as a consequence of the experiences?" Have I had similar experiences? How could I have changed negative incidents that occurred so that such events do not recur in the future? How can I incorporate what I learned into the North American educational system? I must admit that confronting such uncertainties can be an uncomfortable exercise. Still, by addressing these concerns I can empathize with my students when requiring them to ponder their own futures. 


\section{Conclusion}

From the discussion presented in this essay, it is clear that volunteerism as informal learning has value for formal education. My lived experiences as a volunteer fulfilled a personal and professional need that have shaped who I am professionally and personally. I had to travel thousands of miles to many different locations around the world to understand it is the wholeness of a person's life experiences that are important rather than fragmented events. Still, there is another unexpected side that has been informed by my travelling to many developing and post-conflict countries. There are times when I am uncertain where I truly belong and yet cannot wait to get there.

\section{References}

Dewey, J. (1938). Experience and education. New York: MacMillan Publishing Company.

Freire, P. (1970). Pedagogy of the oppressed. New York: The Continuum International Publishing Group.
Kolb, D. (1984). Experiential learning: Experience as the source of learning and development. Englewood Cliffs, NJ: Prentice-Hall, Inc.

Mezirow, J., \& Associates. (1990). Fostering critical reflection in adulthood: $A$ guide to transformational and emancipatory practice. San Francisco: Jossey-Bass.

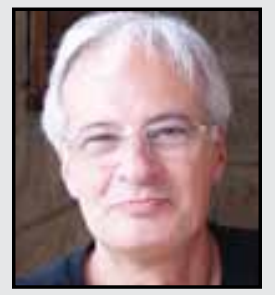

Irving Lee Rother is an award-winning educator whose experience includes teaching, volunteering, consulting, advising, and designing curriculum at the school, university, provincial, and international levels in a variety of disciplines with diverse educators and students. In April 2011, Dr. Rother was nominated for Canada's Prime Minister's Award of Teaching Excellence. Since 2003, Dr. Rother has volunteered with hundreds of youth and educators in Palestine, Nigeria, South Africa, and Kenya. He was one of six Canadians invited to participate in Education, Democracy and Identity in Conflict Areas, a conference held at the University of Bethlehem attended by over a hundred Palestinian educators. 